\title{
Antinomy of the Artistic and Commercial Value of Art*
}

\author{
Maria Matyushova \\ Department of Ontology and Theory of Knowledge \\ Peoples' Friendship University of Russia \\ Moscow, Russia \\ maria_matushova@mail.ru
}

\begin{abstract}
The article deals with the relationship between the artistic and the commercial value of art. The author shows the evolution of aesthetic consciousness, arguing that the artistic value of a work of art was directly connected with the work of a genius until the end of the 19th century. The commercial value of art arises with the appearing art market in the middle of the 19th century, which becomes the main way of regulating artistic life.
\end{abstract}

Keywords-art market; artistic value of a work of art; commercial value; antinomy

\section{Introduction}

There are many questions regarding modern art. Are there any criteria for defining a masterpiece in contemporary art? Of what kind are they? Are they similar to a classical work of art or others? For example, does anyone have an enjoyment or catharsis from the cubistic compositions of Picasso, Kandinsky, and Malevich's «Black Square»? May the notion of a catharsis become outdated for the 20th and 21st century, and do we need an introduction of other aesthetic categories to characterize the feelings derived from the perception of abstract art? How does the concept of a masterpiece in art relate to its commercial value?

It is difficult to answer all these questions in this article; therefore, the author will consider only one aspect - the analysis of the concept of the art market and the role of the Artist in it.

\section{The Appearance of the Art Market}

In modern art dictionaries, the art market is defined as a system of economic and cultural relationships in the field of fine arts, under which demand and supply for art objects are formed, and their aesthetic value and material value are

*This paper was financially supported by the Ministry of Education and Science of the Russian Federation on the program to improve the competitiveness of Peoples' Friendship University (RUDN University) among the world's leading research and education centers in the 2016-2020 (The Agreement number 02.A03.21.0008) determined.

As we see from the definition, exactly the market determines aesthetic and commercial value of the work of art. But how are these two values related to each other?

Until the end of the 19th century the aesthetic value of the work of art was directly connected with the work of a genius personality. The axiom of critics and artists was the assertion that the highest achievements of culture, the progress of culture in general and the art in particular, are associated with the cult of Genius. Especially the romantics thought much about the role of a Genius and his prophetic power and creative abilities. Genius is the medium with the horn or hand, which is led by God, and since for thousands of years it has been recognized that God is the source of power on earth, and power has always been surrounded by respect, then part of this honor and respect went to the genius. According to the generally accepted opinion, Genius was the product of a higher power and its creative or scientific activity was acceptable to this higher power.

The authorities have always tried to surround themselves with ingenious people, thereby strengthening their authority and at the same time giving the genius a halo of chosenness. For example, in the Renaissance, the origin and wealth were very much appreciated, but above all there was the possession of creative talent, rich imagination and fantasy.

The commercial value of art historically arose in the middle of the 19th century. At this time it became the main way of regulating artistic life. An art market, which included merchants of works of art and exhibitions, was created. Auctions and sales were organized. Catalogs and special magazines were published. In addition, the collectors, art critics, museum specialists were also included in this system.

The relationship «customer-artist» existed in the Ancient World, in the Middle Ages and in the Renaissance. The market arose when intermediaries appeared between the customer and the artist. This happens when we not only admire the artistic value of a particular work of art, pay for it to the artist, but also when the work of art becomes a kind of equivalent to money, fulfilling the function of the value of a commodity, the function of circulation and exchange. 
However, having arisen, the art market started to develop to a different scheme than the general economic market. In a market economy, competition contributes to the fact that high-quality goods are replacing substandard goods. Here, the law of supply and demand and the market advantage are rigidly applied in comparison with a centralized economy. As for competition in the art market, everything is the other way around here - quality works of art replaced by low-quality goods. Why is this happening? What is the basis for the existence of such a phenomenon?

\section{Invasion of Money into Art}

Apparently, one of the factors in the emergence of the art market is the emergence of a mass culture, which, in fact, is a «mosaic» consisting of different directions, and is designed for different tastes. This artistic diversity, at first glance, is a virtue of the art of the end 19th - the early 20th centuries, but it is largely due to the lowering and averaging of artistic value of the art works. It is not so noticeable at the beginning of the century, but at the end of the 20th century and the beginning of 21 st century there is a crisis, which we observe both in literature and in painting. Vulgarity and primitivism spread with the speed of a virus and it is possible to ascertain the epidemic of this disease.

As F. Nietzsche correctly noted, "If the artist does not raise his audience with him, the audience quickly descends, and, moreover, falls deeper and more dangerous, the higher the genius rises ...”[1].

These processes indicate that in the modern art world there is a steady invasion of money into art. Money has completely won art; in fact, art has become a type of money. Today, many peoples see the purpose of art in money creation. Artistic value guaranteed by money, critique is also defeated by money.

This is a kind of aestheticizing of money and a change values in society: Andy Warhol once remarked that business is an art, and on the other hand, art itself becomes business and making money. Thus, an analogy is made between making money in business and the creative process in art, because these phenomena are caused by the same motives. Consequently, a new hierarchy of values is built in which the occupation of business has a higher status than the artist's creative activity. Money no longer supports art, but on the contrary, art serves and supports money. Wordseternal, transcendent, genius - went out from the lexicon of artists and of people, who buy an artwork. This very same product turns into a financial document.

Earlier art was a manifestation of the spirit, soul, ideas in a material form, but now the 'Spirit' of money in art has become universal and it no longer idolizes art, but this «Money spirit». This spirit is, in fact, the criterion of the true value of works of art, and, sometimes people who are indifferent to art, hearing about big price paid for paintings, begin to be interested in paintings.

Thus, the increase in demand for works of art does not indicate the development of aesthetic taste, the interest in creativity, but, on the contrary, first of all, it shows how much power money has in the modern world.

So is there a difference between commercial value and artistic value? Most likely, today in the public consciousness and in the minds of many artists this difference does not exist and it is possible to say with certainty that the commercial value of works of art has subordinated to itself its spiritual value, moreover, it determines it.

The aesthetic, cognitive, emotional value of art-all this became subject to material value in its monetary dimension.

Of course, art has always been not free of, but now it has become very dependent on money. Especially regarding investments in art. Investments are identified with admiration, a kind of deification, the highest achievement, the treasure of culture. Today, hyper investment suppresses art, showing that money is above any artistic value.

Investments in works of art during periods of economic crises, wars and other extreme situations are extremely attractive and are rightly considered a «safe haven» for big capital. Many analysts, which study the behavior of prices for works of art over a long period, came to this conclusion. As an example, the prices for the work of Paul Cezanne in Germany did not go down during either the First or Second World Wars as in comparison with government securities.

Modern art is indeed in a sense an investment tool. Business in the art is very similar to securities transactions, in which - the artist is an issuer, those who produce products, 'prints' money - works of art, the exhibition is a kind of emission, the release of these 'money' — a work of art.

Thus, money to some extent closes the way to critical consciousness, to an objective evaluation of the artistic significance of the picture, for the price of a work of art in the contemporary art market becomes the most 'objective and independent' criterion of its artistic value. In addition, low prices indicate short-term investments, while high prices indicate long-term investments and the priceless works that seem to confirm the immortality of art.

\section{Iv. Globalization of the Art Market}

Today we see a rise in the art market, the world of art has expanded more than ever before. Now a global world art market includes such countries as Russia, China, Japan, and United Arab Emirates. Now in total, the art market has around 5 thousand auction houses of different levels in the world. In the 90's of the last century dealers talked about the crisis, the recession, now many of them are very optimistic. In connection with these, researchers of contemporary art raise the question: does the art market have cycles? The answer will be - of course, yes, but the art market is not so much associated with shocks in society. Economic crises affect traditional markets, but not necessarily the art market: crises in the art market are not related to the problems of the world economy. For example, the prices for art did not fall 
as a result of the terrorist act of September 11 and the war in Iraq

The activity of the market, in particular, is observed when works created in the post-war era and works of modern authors are exhibited at the auction. Investors around the world are closely watching the state of affairs at auctions, as against the background of the global crisis of stock markets people are looking for alternative and effective investment tools.

Many collectors, seeing a crisis in the economy, withdraw money from securities and invest them in objects such as real estate, jewelry, precious metals, and more often art objects. There is a tendency to diversify investments, for example, most Russian collectors for an investment of US\$100 million, would not but buy one painting of Picasso, but one hundred paintings of famous Western authors for one million dollars each.

What attracts collectors, what 'shares' in the art market are the most popular? This, of course, works of old masters, impressionists and modern art.

The main center in the US art market is New York: it is here that $42 \%$ of all transactions in the country are made. Of the 100 largest auction sales in the world 59 committed in New York at Sotheby's or Christie's. There are also representative offices of about 2 thousand of the largest art dealers out of 25 thousand registered in the United States.

The largest market after the US is the UK market according to researchers. Among other European countries, France and Germany stand out. German art dealers are in the main centers - Munich, Berlin, Cologne and Dusseldorf, and many of the auctions are scattered around the country more freely.

In recent years, the most significant changes have occurred in the art market of China. The Chinese art market began to emerge from the 1990s as part of Deng Xiaoping's Open Doors policy, which meant opening the country to cultural influence from abroad. A key figure in the early development of the market was Johnson Chang, a curator and art dealer from Hong Kong, who along with Li Xiantin, an influential art critic, played an important role in developing a global interest in Chinese contemporary art. ART HK was founded in 2008 and quickly became established as the leading event of its kind in Asia.

As for India, this market is entering a phase of formation.

Brazil has the world's oldest biennial of arts in São Paulo (since 1951), and recently there have also been art fairs in Sao Paulo and Rio de Janeiro, (started in 2007 and 2011) and since then they attract more attention to prestigious galleries.

In Russia, investment in art is attractive not only because it is new, fashionable, but also because it is prestigious, because the history of Russian culture is rich in examples of private gathering: the Stroganovs, Demidovs, Schukins, Bakhrushins, Morozovs and many others have acquired, preserved, and contributed to the recognition of many works of Russian and Western European culture.
Thus, the segmentation of the market is changing, and this means that new customers have appeared and that the art market, which previously mainly relied on European buyers becomes international. There is a gallery infrastructure, faculties in the economy and management of the art market, curators, expertise, collectors, analysts, insurance. There is a huge number of different associations: The International Federation of Dealer Associations (CINOA), The Association of Art \& Antiques Dealers (LAPADA), The Antiquities Dealers Association (ADA) and The International Association of Dealers in Ancient Art (IADAA), etc.

In addition, the globalization of the art market is now directly connected to the Internet. In fact, since the birth of the Internet, people no longer need to spend time visiting their local galleries; many collectors prefer to view art works on the Internet - not only because it is convenient, but also because the Internet gives the opportunity for a wider selection of works that interest him. In addition, they can now immediately check the information on prices on the Internet when buying at an art fair.

\section{v. The Change the Concept of 'Art'}

The market has changed the very concept of art. In the Middle Ages the concept of art is expressed in the definition given by Quintilian: "Art is a methodological skill", or "art is the ability to work in a certain order" - it is the knowledge of the rules by which you can create certain things and the knowledge of the rules which already existing, objective rules. Art included any human activity: science, dialectics, astronomy, medicine, agriculture, architecture, building a ship and a house, making a hammer and drawing a miniature. Art was identified with craft, technique, and the theory of art was the theory of craft. The term 'artifex' 'artist' refers to a person who is versed in any profession. Moreover, even this term was applied to God. God is the most skillful architect of the world, a goldsmith, sometimes a blacksmith, and chaser. The creative process was likened to the divine creation: the artist creates exactly the same way that God once created the world.

XIX century and the vanguard changed everything. The term "work of art" was replaced by the word "project", or artifact. The project is a composite product; it is the combined efforts of the gallerist, advertisement, curator, artist, and dealer. Actually, the artist's work occupies a negligible part in it. "We are opposed to recognizing that all sectors of our life have been in the sphere of goods, and even more so - that they were in the fashion field. The point is that the liquidation of values is particularly radical. Under the power of the commodity, all kinds of labor are exchanged for each other and lose their particularity under the rule of fashion, labor itself and leisure as such change their signs. Under the power of the commodity, culture is sold and bought - under the power of fashion, all cultures are mixed together in a total game of simulacra" [2]. 
Previously, people admired the works of arts, but they were not particularly interested in the personality of the author, they bought specific works, not names: both in antiquity and in the Middle Ages and the Italian Renaissance showed little interest in the creator himself attention was focused on his creations.

In newer times, many people have interest to personality of the artist, his social role - the market wants to know information about the artist; what brand of clothing the artist wears, what he drinks, with whom and where he spends rest.

The artist's work does not cost anything, but, passing through the appropriate authorities (the gallery's opinion, the curators' recommendations, museum certificates), it turns into a commodity. And each of the instances has its own material interest and, accordingly, increases the commodity value of the product. The creative process, as a rule, takes a little time: paint the square, draw lines, call it all composition or improvisation, and arrange an exhibition and the works are ready. At the same time, the accompanying activities (organization and presentation of exhibitions, advertising, press, transportation, insurance, catalogs, films, etc.) require a lot of money, and the cost of this process is included in the total price of the work.

\section{Role of Advertising}

Of course, the profit from the art entirely depends on advertising. Declaring this art a symbol of free expression, the curator has the right to expect that civilization (which proclaims freedom as its main goal) will pay this symbol well. The profession of the curator has become much more important for art than the work of the artist. Advertising becomes a gigantic force and its task is to master the mind of the consumer, eliminating the difference between what seems and what is. Everything can be good or bad, depending on a product's reputation, which is formed by experts and dealers. It is necessary to force the nonprofessional person to believe that this or that picture is a true miracle. Of course, the buyer is not so stupid to accept this good news with complete naivety, until the end and here the great importance is convincing, even the speaker's skill of the dealer.

There is a situation when painting, which is based on the image of the object, comes into direct dependence on words - art business is determined by oral or written praise and assurances that convince the buyer of the high value of the work and, accordingly, at a high price. It turns out that people who buy paintings perceive it with their ears, and not with their eyes, to select works based not on the «disinterestedness of the aesthetic sense» that I. Kant spoke of but on the law of market relations. This was very well said by F. Nietzsche that contemporary art loses its main function - the function of delivering aesthetic pleasure, affecting primarily feelings: "The more the eye and ear become capable of thinking, the more they approach the border where they become insensitive: pleasure is transferred to the brain, the senses themselves are dull and weaker, the symbolic is increasingly taking the place of the real - and, thus, on this path, we are as surely attaining barbarism as on any other" [3].

Advertising is modern alchemy and it is able to turn anything into gold, true, this gold does not exist in reality, but only in the mind of the buyer. Advertising works on the well-known principle of subjective idealism «without a subject there is no object». The value of things exists only in the mind, but the money that people spread out exists independently of consciousness.

\section{vII. Conclusion}

Is this trend of rapprochement between art and money identification of works of art with money useful or harmful to the artist, in general for society?

This tendency, in the final analysis, destroys the artistic taste in society, since earlier the entire education system has been aimed at the formation of a highly artistic taste that would allow a person to distinguish between bad art and good art, talented from the non-talented. Now, as a result of commercialization, these landmarks are lost. Earlier, when creating a work of art, the artist used technical skill, original design, experience, knowledge, work. All this was necessary for work - but this was not enough. He put his fantasy, the whole soul into the work, and there was a feeling the secret of creativity, inexplicable by any critics.

The market turns a work of art into a financial document: a check, a bond, a share, or a cash bill. The stable glory of genius is the virtual bank that issues guarantees to collectors, and thus insures them from bad luck.

The question arises: is it a natural tendency that arises from the necessity of a state of modern mass postindustrial society and its liberal ideology, or is it a deviation from the norm of development of life, including spiritual life? If this statement is true, then it is necessary to look for ways to change life, giving it the natural forms of development stemming from its nature.

The processes that have occurred and are taking place in art in recent decades are reminiscent of the artificial breakdown of the natural historical process and contradict the main line of cultural development that is directly related to the image of Man, the Beautiful, and the Truth.

\section{References}

[1] F. Nietzsche, Menschliches, Allzumenschliches: - M: Alphabetclassics, 2008, p. 168.

[2] J. Baudrillard J. Symbolic exchange and death: - M .: Dobrosvet, 2000, p. 170

[3] F. Nietzsche, Menschliches, Allzumenschliches: - M .: Alphabet classics, 2008, p. 217 